\title{
Scintillation and optical properties of polycrystalline $p$-terphenyl
}

\author{
T.E.Gorbacheva, N.Z.Galunov, V.D.Panikarskaya, I.V.Lazarev \\ Institute for Scintillation Materials, STC "Institute for Single Crystals", \\ National Academy of Sciences of Ukraine, \\ 60 Lenin Ave., 61001 Kharkiv, Ukraine
}

Received April 1, 2013

\begin{abstract}
The work is devoted to study of scintillation and optical properties of polycrystalline $p$-terphenyl obtained by hot pressing of powders of different dispersion. The influence of grain size of the powders on the light output and optical transparency of the polycrystalline samples was studied. It was shown that the grain size in the range of $2.2-3 \mathrm{~mm}$ is optimal for registration of short-range radiation at the selected sample thickness. Using such grain size it is possible to get the light output of the polycrystalline scintillator of about 50-75\% relatively to one of the single crystal. It was also shown that low optical transparency is the major factor deteriorating the scintillation characteristics of the samples with relatively small grains.
\end{abstract}

Исследованы сцинтилляционные и оптические характеристики поликристаллов $n$ терфенила, полученных методом горячего прессования из порошков различной дисперсности. Изучено влияние размера зерен порошков на световой выход и оптическую прозрачность поликристаллов. Показано, что размер зерна порядка 2,2-3 мм является оптимальным для регистрации короткопробежных излучений, при выбранной толщине образца. При этом удается получить световой выход поликристаллического сцинтиллятора 50-75 \% относительно монокристалла. Также показано, что основным фактором, ухудшающим сцинтилляционные характеристики при относительно малых размерах зерен, является снижение оптической прозрачности.

\section{Introduction}

Organic luminescent materials with low effective atomic number have an advantage comparing with non-organic ones in shortrange radiation ( $\alpha$ - and $\beta$-particles) detection. One of the ways to improve shortrange radiation detection efficiency is to increase the area of the sensor. However, the most effective organic scintillators - organic single crystals does not allow making detectors with a diameter greater than $80 \mathrm{~mm}$ with maintaining high scintillation characteristics [1-3]. Detectors with large area can be made using composite materials $[4,5]$ and sintering (hot and cold pressing) $[6,7]$. The technology of organic polycrystalline detectors production allows making detectors of large diameter (the size of which is limited only by the mechanical strength of these systems). However, polycrystalline scintillators have a number of drawbacks. The one of the main drawbacks is low optical transparency that is especially critical for registration of short-range radiation in the most detectors with classical geometry.

The main objective of this work was to study effect of the size of grains in starting material on the optical transparency and scintillation characteristics of the hotpressed $p$-terphenyl polycrystalline samples.

\section{Experimental}

Hot pressing of starting crystalline scintillation material was carried out by uniaxial compression at $165^{\circ} \mathrm{C}$ with consequent slow cooling to room temperature. As 

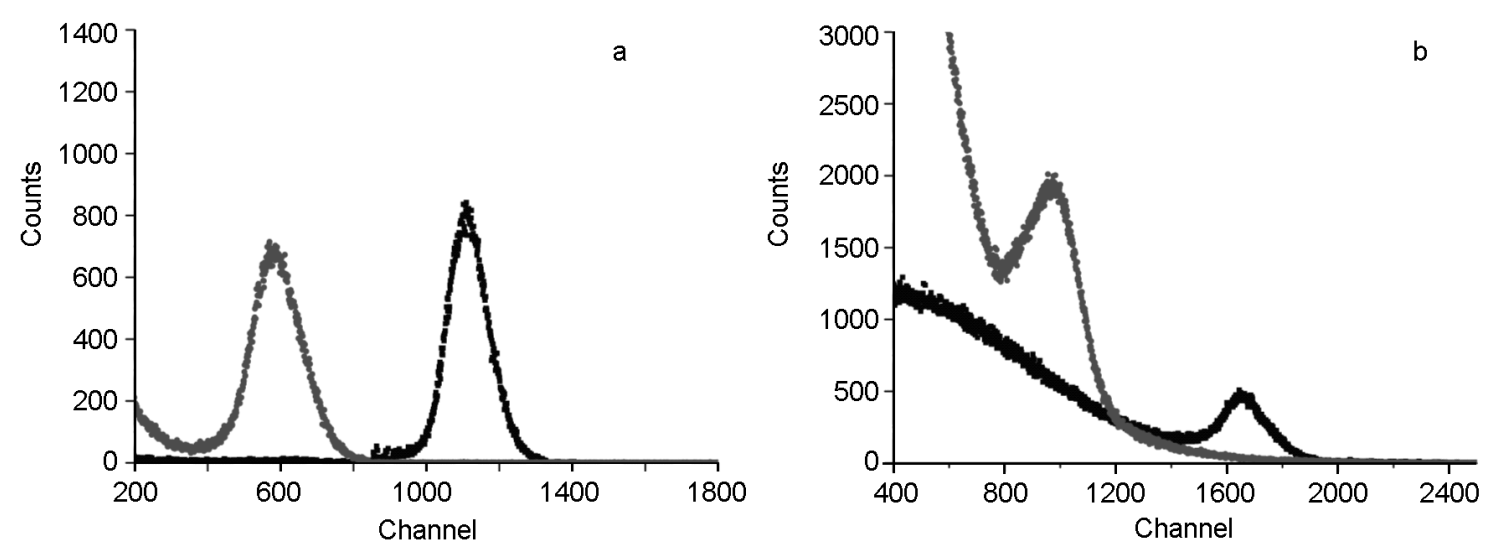

Fig. 1. Pulse height spectra of $p$-terphenyl polycrystalline scintillators (made by the method of hot pressing) under registration of ${ }^{239} \mathrm{Pu} \alpha$-radiation with $E_{\alpha}=5.15 \mathrm{MeV}$ (a) and ${ }^{137} \mathrm{Cs}$ conversion electrons with $E_{e}=0.624 \mathrm{MeV}$ (b).
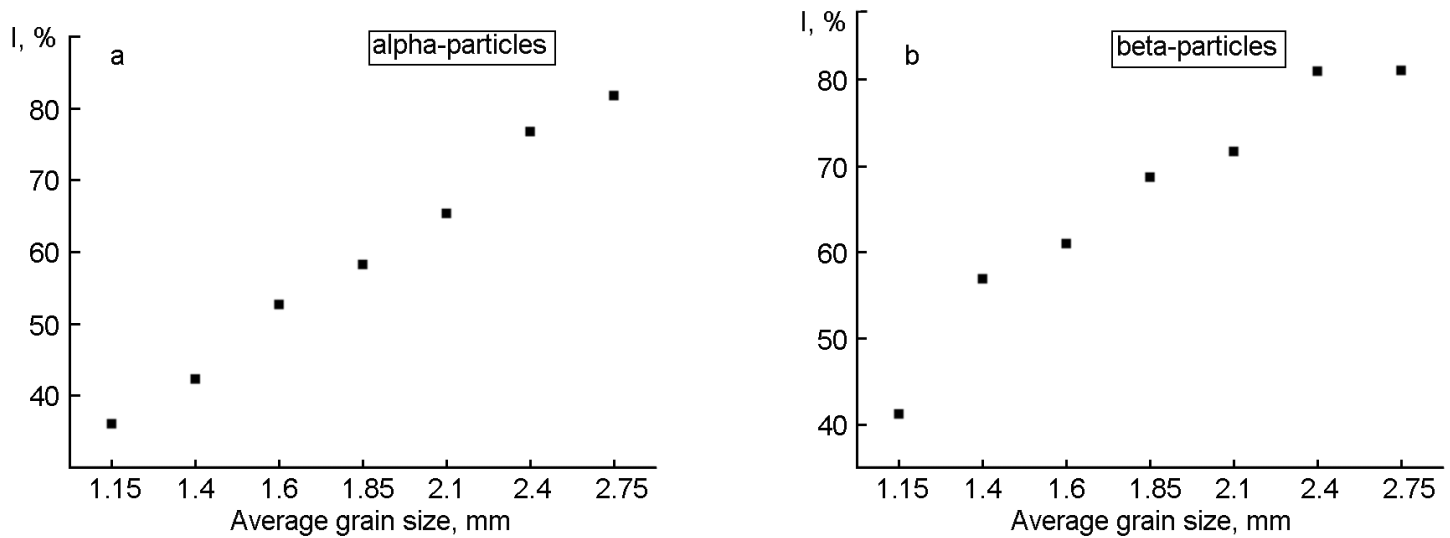

Fig. 2. Dependence of light output on the grain size under registration ${ }^{239} \mathrm{Pu} \alpha$-radiation with $E_{\alpha}=5.15 \mathrm{MeV}$ (a) and ${ }^{137} \mathrm{Cs}$ conversion electrons with $E_{e}=0.624 \mathrm{MeV}$ (b).

a starting material, we used thermally crushed single crystal. This temperature corresponds to the value of $0.9 T_{m p}$. Pressing at temperatures above $165^{\circ} \mathrm{C}$ resulted in the sublimation of $p$-terphenyl. Compaction pressure of $30 \mathrm{MPa}$ was adopted. Such a low pressure was selected basing on the results obtained in the study of the characteristics of polycrystalline stilbene during hot pressing. Press force equal to the specified value was applied after reaching the temperature of $165^{\circ} \mathrm{C}$. Then, exposure was conducted at constant preset parameters within $60 \mathrm{~min}$. Then, the press force was no longer applied and it spontaneously fall to zero within 20-30 min. Heater was also turned off and natural cooling to the room temperature occurred at a rate of about $1^{\circ} \mathrm{C} / \mathrm{min}$ during $3 \mathrm{~h}$.

We carried out a comparative study of the scintillation characteristics of organic polycrystalline $p$-terphenyl $\varnothing 30 \mathrm{~mm} \times 5 \mathrm{~mm}$ with different grains size $L$ that was obtained by described hot pressing method. In this work a series of seven $p$-terphenyl polycrystalline scintillators with different grains sizes was investigated. The following fractions were used: $L=1.0-1.3 \mathrm{~mm}$, 1.3-1.5 mm, 1.5-1.7 mm, $1.7-2.0 \mathrm{~mm}$, 2.0-2.2 mm, 2.2-2.5 mm, 2.5-3.0 mm. As a reference sample, the p-terphenyl single crystal scintillator with the same thickness ( $5 \mathrm{~mm}$ ) and diameter $30 \mathrm{~mm}$ was used. For the comparative analysis of the light output of the polycrystalline samples, we measured amplitude spectra under irradiation by the following sources of ionizing radiation: ${ }^{137} \mathrm{Cs}$ (conversion electrons with energy $0.624 \mathrm{MeV}$ ) and ${ }^{239} \mathrm{Pu}(\alpha$-particles with energy $5.15 \mathrm{MeV}$ ). As a photo detector, we used photomultiplier R-1307 made by "Hamamatsu" company. The value of relative light output can be calculated using the results of measurements of amplitude spectra.

Optical transmittance of the pressed polycrystalline $p$-terphenyl, obtained by the method of hot pressing was measured by spectro- 
T.E.Gorbacheva et al. / Scintillation and optical ...

Table. Average optical transmittance for the samples with different grain size

\begin{tabular}{||c|c|c|c|c|c||}
\hline \multirow{2}{*}{ Samples } & Grain size & \multirow{2}{*}{$\begin{array}{c}\text { Average grain } \\
\text { size, } L_{a v}\end{array}$} & \multicolumn{3}{|c||}{ Transmittance, \% } \\
\cline { 4 - 6 } & & $\lambda=360 \mathrm{~nm}$ & $\lambda=390 \mathrm{~nm}$ & $\lambda=700 \mathrm{~nm}$ \\
\hline 1 & Single crystal & 0 & 54.3 & 66.6 & 79.7 \\
2 & $1.0-1.3$ & 1.15 & 5.8 & 6 & 15.9 \\
3 & $1.3-1.5$ & 1.45 & 7.24 & 8.3 & 16.4 \\
4 & $1.5-1.7$ & 1.6 & 8.5 & 10.5 & 17.3 \\
5 & $1.7-2.0$ & 1.85 & 9.3 & 11 & 18.1 \\
6 & $2.0-2.2$ & 2.1 & 10.5 & 13 & 19 \\
7 & $2.2-2.5$ & 2.35 & 11.4 & 14.2 & 21.8 \\
8 & $2.5-3.0$ & 2.75 & 12.3 & 16.6 & 19.7 \\
\hline
\end{tabular}

photometer "Shimadzu". Measurements were carried out using an integrating sphere.

\section{Results and discussion}

Amplitude spectra of the single crystal and polycrystalline specimens that were measured using ${ }^{137} \mathrm{Cs}$ source (conversion electrons with energy $0.624 \mathrm{MeV}),{ }^{239} \mathrm{Pu}$ ( $\alpha$-particles with energy of $5.15 \mathrm{MeV}$ ) and $\gamma$-radiation from ${ }^{137} \mathrm{Cs}$ are shown in Fig. 1.

Fig. 2 shows the results of calculations of the relative light output $J$ for the organic polycrystals. The measurement error did not exceed the methodological errors of the light output values and was $5 \%$ at a confidence level 0.95 .

In the course of studies in order to establish a correlation between the parameters of hot pressing process and the characteristics of organic polycrystalline $p$-terphenyl a major preliminary result was obtained, which allows to determine the effect of transparency (optical transmittance in the visible region of the spectrum $T, \%$ ) on the light output of the polycrystalline samples excited by the short-range radiation [3]. The optical transmittance hot pressed polycrystalline $p$-terphenyl samples was measured using spectrophotometer "Shimadzu". Measurements were made using an integrating sphere. The mean values of the optical transmission of the samples obtained by hot pressing are shown in Fig. 3 and 4. These data correlate with the results of the above measurements of the light output of the same polycrystalline stilbene samples $(5 \mathrm{~mm}$ thick) under short-range alpha-particles irradiation (see Fig. 2).

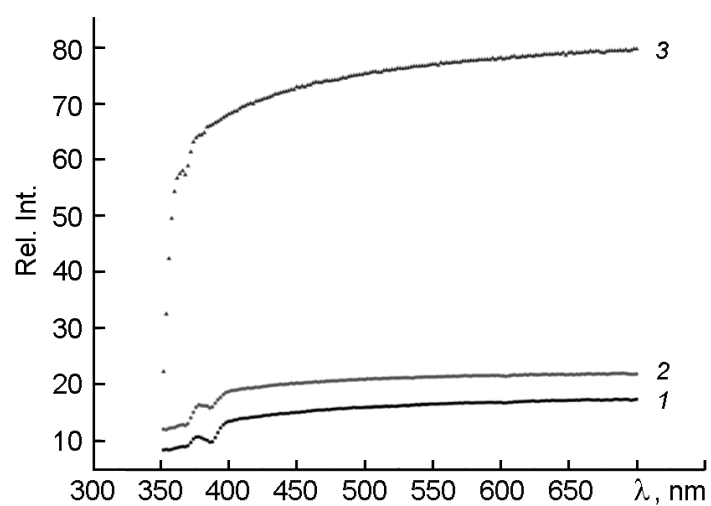

Fig. 3. Dependences of light output on grain size $(1-$ polycrystalline samples with grain size $1.2-1.5 \mathrm{~mm}, 2$ - polycrystalline samples with grain size $2.4-3 \mathrm{~mm}, 3-p$-terphenyl single crystal).

\section{Conclusion}

Thus, conducted studies have shown that for the registration of short-range radiation is desirable to use polycrystalline scintillators with the large size of the grains. However, the measurements of the optical transparency identified saturation effect and even recession of the transmittance $T$ at short wavelengths with increasing of the grain size. This effect begins to appear when the grain size is higher than $2 \mathrm{~mm}$. Consequently, for polycrystalline $p$-terphenyl scintillator obtained by hot pressing the optimal grain size of the starting material is between $2.2-3 \mathrm{~mm}$. In this case it is possible to obtain light output of the polycrystalline scintillator of about 50-75\% relatively to the one of the single crystal. 


\section{References}

1. J.B.Birks, The Theory and Practice of Scintillation Counting, Pergamon Press, London (1967).

2. N.Karl, in: Proc. Inst. Phys. Conf. Ser. Cambridge, IOP Publishing LTD, No.103, Section 2.1 (1989), p.107.

3. E.A.Silinsh, V.Capek, Organic Molecular Crystals: Interaction, Localization and Transport Phenomena, American Institute of Physics, New York (1994).
4. S.K.Lee, Y.H.Cho, B.H.Kang et al., Progr. Nucl. Scie. and Techn., 1, 292 (2011).

5. J.Iwanowska, L.Swiderski, M.Moszynski et al., J. Instrument., 6, 1 (2011).

6. N.Z.Galunov, J.H.Baker, S.V.Budakovsky et al., J. Luminescence, 102, 464 (2003).

7. S.V.Budakovsky, N.Z.Galunov, N.L.Karavaeva et al., IEEE Trans. Nucl. Sci., 54, 2734 (2007).

\section{Дослідження сцинтиляційних і оптичних властивостей полікристалічного $n$-терфенілу}

\section{Т.С.Горбачова, М.З.Галунов, В.Д.Панікарська, І.В.Лазарєв}

Досліджено сцинтиляційні і оптичні характеристики полікристалів $n$-терфенілу, отриманих методом гарячого пресування 3 порошків різної дисперсності. Вивчено вплив розміру зерен порошків на світловий вихід і оптичну прозорість полікристалів. Показано, що розмір зерна 2,2-3 мм є оптимальним для реєстрації короткопробіжних випромінювань при вибраній товщині зразка. При цьому вдається отримати світловий вихід полікристалічного сцинтилятора 50-75 \% щодо монокристала. Також показано, що основним чинником, що погіршуе сцинтиляційні характеристики при відносно малих розмірах зерен, є зниження оптичної прозорості. 